\title{
Recurrent Angioedema with Abdominal and Genital Involvement in Childhood: Hereditary Angioedema Type 2 Disease due to C1 Inhibitor Functional Deficiency
}

\section{Genital ve Karın Bölge Tutulumuyla Giden Çocukluk Çağında Tekrarlayan Anjioödem: C1 İnhibitör İşlevsel Eksikliğine Bağlı Herediter Anjioödem Tip 2 Hastalığı}

\author{
(1) Öner Özdemir1 1 (1) Halime Çiçek² \\ 1Sakarya University, Sakarya Training and Research Hospital, Clinic of Pediatric Allergy and Immunology, Sakarya, Turkey \\ 2Sakarya University, Sakarya Training and Research Hospital, Clinic of Pediatrics, Sakarya, Turkey
}

\begin{abstract}
Hereditary angioedema is a rare disorder characterized by recurrent angioedema attacks due to $\mathrm{C} 1$ inhibitor antigen or functional deficiency. Here, two cases with recurrent swelling on extremities, genital organs and face that were later diagnosed with C1 inhibitor functional deficiency (hereditary angioedema type 2) were presented. The first patient was an 8-year-old boy complaining of hand and foot swelling recurring once a year for the last 4 years. He was more frequently brought to outpatient pediatric clinics because of his recurring complaints in the last 5 months. In prodromal period, he had erythema marginatum-like rash and sometimes described abdominal pain with swelling. The second patient was an 11-year-old girl complaining of abdominal pain and facial swelling recurring in a couple of months for the last 8 years. Her grandfather, father and uncle had the same angioedema. In their laboratory evaluation, complement C4 levels were both found as low at $<0.07 \mathrm{~g} / \mathrm{L}(>0.1)$. Although C1 inhibitor antigen levels were both in reference range, its function tests were detected as low at $31 \%$ and $43 \%(>70 \%)$, respectively. Therefore, in cases with pediatric recurrent angioedema without urticaria, hereditary angioedema should be considered. After screened with C4 level, if required, both $\mathrm{C} 1$ inhibitor antigen and function tests are evaluated.
\end{abstract}

Keywords: Hereditary angioedema, abdominal pain, genitalia, childhood, C1 inhibitor

\section{öZ}

Herediter anjioödem C1 inhibitor antijen ya da ișlevsel eksikliğine bağı tekrarlayan anjiyoödem ataklarıyla bilinen nadir bir bozukluktur. Burada ekstremitelerde, genital organlarda ve yüzde tekrarlayan şişlikleri nedeniyle C1 inhibitor ișlevsel eksikliği (herediter anjiyoödem tip 2) tanısı konulan iki olgu sunulmuştur. Sekiz yaşındaki erkek çocuk el ve ayaklarında șişliklerin yılda bir kere son 4 yıldır tekrarladığından şikayet etmekteydi. Son beş ayda tekrarlayan şikayetlerinden dolayı daha sık pediyatri polikliniğine başvurmuştur. Olgu prodrom döneminde eritema marginatum-benzeri döküntü ve şişlikleri esnasında karın ağrısından şikayet etmekteydi. On bir yaşında kız çocuk olan ikinci olgu son 8 yıldır birkaç ayda bir tekrarlayan karın ağrısı ve yüzde şişmeden şikayet ediyordu. Dede, baba ve amcada benzer anjiyoödem mevcuttu. Olguların laboratuvar değerlendirmesinde, kompleman C4 düzeyi $<0,07$ $(>0,1) \mathrm{g} / \mathrm{L}$ olarak düşüktü. Her ikisinde C1 inhibitor antijen seviyesi referans aralı̆̆ı iç̧inde olmasına rağmen fonksiyon testi sırasıyla \%31 ve \%43 (>\%70) olarak düşük bulundu. Dolayısıyla, çocukluk çă̆ı tekrarlayan ürtikersiz anjiyoödemlerinde, herediter anjiyoödem düşünülmelidir. Kompleman C4 düzeyi ile tarama sonrasında, gerekirse, hem C1 inhibitor antijen ve hem de fonksiyon testleriyle değerlendirilmelidir.

Anahtar Kelimeler: Herediter anjioödem, karın ağrısı, cinsel organ, çocukluk çağı, C1 inhibitor

\section{Introduction}

Hereditary angioedema ( $\mathrm{HAO}$ ) is an autosomal dominant inherited disease with recurrent angioedema attacks. HAO is characterized by C1 inhibitor (C1 INH) antigen level deficiency or dysfunction, which regulates the starting proteins of the classical complement system (1). Two main groups of the disease are defined according to whether $\mathrm{C} 1 \mathrm{INH}$ has a protein or functional deficiency. In the main group (C1 INH-HAO), which leads to a deficiency of $\mathrm{C} 1 \mathrm{INH}$, there is a decrease in absolute antigen concentration of $\mathrm{C} 1 \mathrm{INH}$ in Type 1 and a decrease in $\mathrm{C} 1 \mathrm{INH}$ function in Type 2. Besides inhibiting the first element of complement, C1 INH leads to inhibition on coagulation factors, plasminogen, etc. in the coagulation-fibrinolysis activation system. In its deficiency, due to
Address for Correspondence/Yazıșma Adresi: Öner Özdemir MD, Sakarya University, Sakarya Training and Research

Hospital, Clinic of Pediatric Allergy and Immunology, Sakarya, Turkey

Phone: +90 5331371274 E-mail: oner.ozdemir.md@gmail.com ORCID ID: orcid.org/0000-0002-5338-9561

Cite this article as/Atıf: Özdemir Ö, Çiçek H. Recurrent Angioedema with Abdominal and Genital Involvement in Childhood: Hereditary Angioedema Type 2 Disease due to C1 Inhibitor Functional Deficiency. Istanbul Med J 2020; 21(2): 155-9.

(c) Copyright 2020 by the University of Health Sciences Turkey, Istanbul Training and Research Hospital/istanbul Medical Journal published by Galenos Publishing House.

(C) Telif Hakkı 2020 Sağlık Bilimleri Üniversitesi istanbul Ĕgitim ve Araştırma Hastanesi/Istanbul Tıp Dergisi, Galenos Yayınevi tarafından basılmıștır.
Received/Geliș Tarihi: 23.09.2019 Accepted/Kabul Tarihi: 12.02 .2020 
the overwork of this system, bradykinin accumulation occurs in the body and angioedema occurs. The main group of HAO (nC1 INH- HAO), formerly referred to as Type 3, where $\mathrm{C} 1 \mathrm{INH}$ protein level and function is within the reference range, is mainly due to the mutation in the coagulation factor 12, plasminogen or angiopoietin-1 genes and mostly triggered by angiotensin converting enzyme (ACE) inhibitor or estrogencontaining drugs, particularly in women. Rarely, it has been reported to be seen in male cases (1-3).

HAO is a disease seen equally in both sexes and at all ages. Angioedema attacks can affect any part of the body; however, it occurs mostly on the extremities, face, airways, visceral organs, trunk, neck and genital area. Edema in the airways, laryngeal edema is the most common cause of fatality (2). Although its frequency varies from society to society, it is believed that $\mathrm{C} 1 \mathrm{INH}-\mathrm{HAO}$, which is the most common type, has a frequency of 1/50,000-150,000 people in the society. The frequencies of some other types are much rarer (2). Since it is a very rare disease, its diagnosis may be delayed from time to time. Here, a boy with a complaint of swelling in the hands and feet, who has had many polyclinic applications in the last 4 years, and a girl with more facial involvement are presented due to the functional deficiency of $\mathrm{C1}$ INH and the diagnosis of HAO type 2, and being rarely seen in the clinic.

\section{Case 1}

An 8-year-old boy complained of swelling in the hands and feet, which repeated once a year for 4 years. Because his complaints became more frequent in the last 4-5 months and he had swelling of the hands and feet 4 times in the last 1 month, he applied to the child outpatient clinic (Figure $1 \mathrm{a}, \mathrm{b}$ ). The patient had a complaint of rash before the complaint of swelling, but never itching (Figures 2a, b). No previous

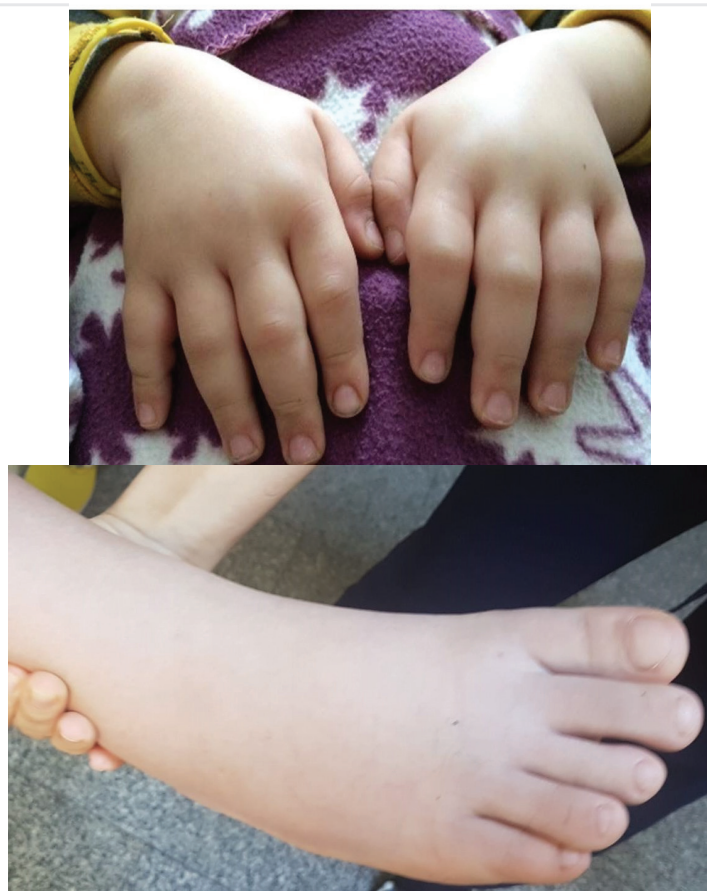

Figure 1a, b. Edema in the hands and feet seen in the attack period of the first case history of infection, exposure to a known allergen, trauma and drug use was described. There was no known history of the disease in his background and family history. In laboratory examinations, hemogram evaluation and biochemical tests were within the reference range. C-Reactive protein, erythrocyte sedimentation rate, serum rheumatoid factor, serum immunoglobulin and C3 values were found to be normal. Thyroid function tests were within the reference range and viral hepatitis serology was negative. There was no positivity in skin prick tests (SPT) and allergen-specific IgE studies applied to the patient. C4 requested for the diagnosis of $\mathrm{HAO}$ was $<0.07 \mathrm{~g} / \mathrm{L}(0.1-0.4)$ and was low. C1 INH antigen level was detected as 24.7 (18- $40 \mathrm{mg} / \mathrm{dL}$ ), which was in the reference range. The patient was followed up with a pre-diagnosis of chronic urticaria-angioedema in the outpatient clinic. Because C4 and C1 INH antigen level tests that could be performed in the hospital were within the reference range, the diagnosis of HAO was avoided in the first plan. C1 INH activation/function test was requested because when the boy presented to the child allergy outpatient clinic, a typical rash during the prodrome period (Figures 2a, b) was observed and he stated that he sometimes had abdominal pain with swelling. Considering C1 INH function test result of 31\% (70-130\%), the patient was diagnosed with $\mathrm{C} 1 \mathrm{INH}-\mathrm{HAO}$ type 2 and Icatibant therapy was started. The case was admitted to the Pediatric Emergency Department with a complaint of swelling in his hand after a few weeks and he was evaluated to have had

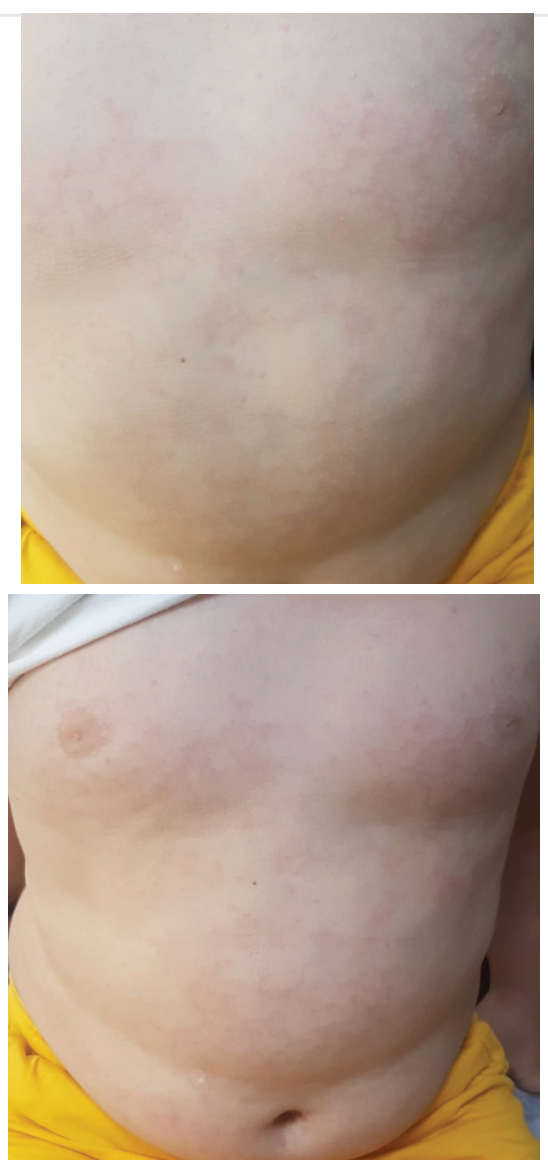

Figure $2 \mathrm{a}, \mathbf{b}$. Erythema marginatum-like rash in the body seen in the prodrome period of the first case 
a HAO attack and Icatibant 15 mg was administered subcutaneously. Two-three days after this treatment, the patient complained of swelling and mild pain in the penis and scrotum area and he applied to the child allergy outpatient clinic. His physical examination revealed no signs of pathological examination except for tenderness with palpation and edema in the scrotum and penis (Figures 3a, b). Scrotal ultrasonography which was performed for ruling out epididymitis revealed edema in the scrotum wall. Complete urine test was evaluated within the reference range. The complaints of the patient were thought to be related to angioedema. The patient was hospitalized in the child allergy clinic and $15 \mathrm{mg}$ Icatibant was subcutaneously administered to the patient in accordance with the drug posology (weight) $(0.4 \mathrm{mg} / \mathrm{kg}$; maximum $30 \mathrm{mg}$ ). Because the edema in the penis and scrotum was reduced in the follow-up, the patient was discharged with healing. The followup of the patient is still ongoing, and his attacks are under control (written informed consent was obtained from the child's family for the presentation).

\section{Case 2}

An 11-year-old girl had recurrent abdominal pain, swelling in the face and eyes for 7-8 years. Since the age of 3-4 years, she had abdominal pain that lasted two days every 2-3 months. While teething in the $1^{\text {st }}$ and $3^{\text {rd }}$ grades of primary education, she had swelling on the face. Her most

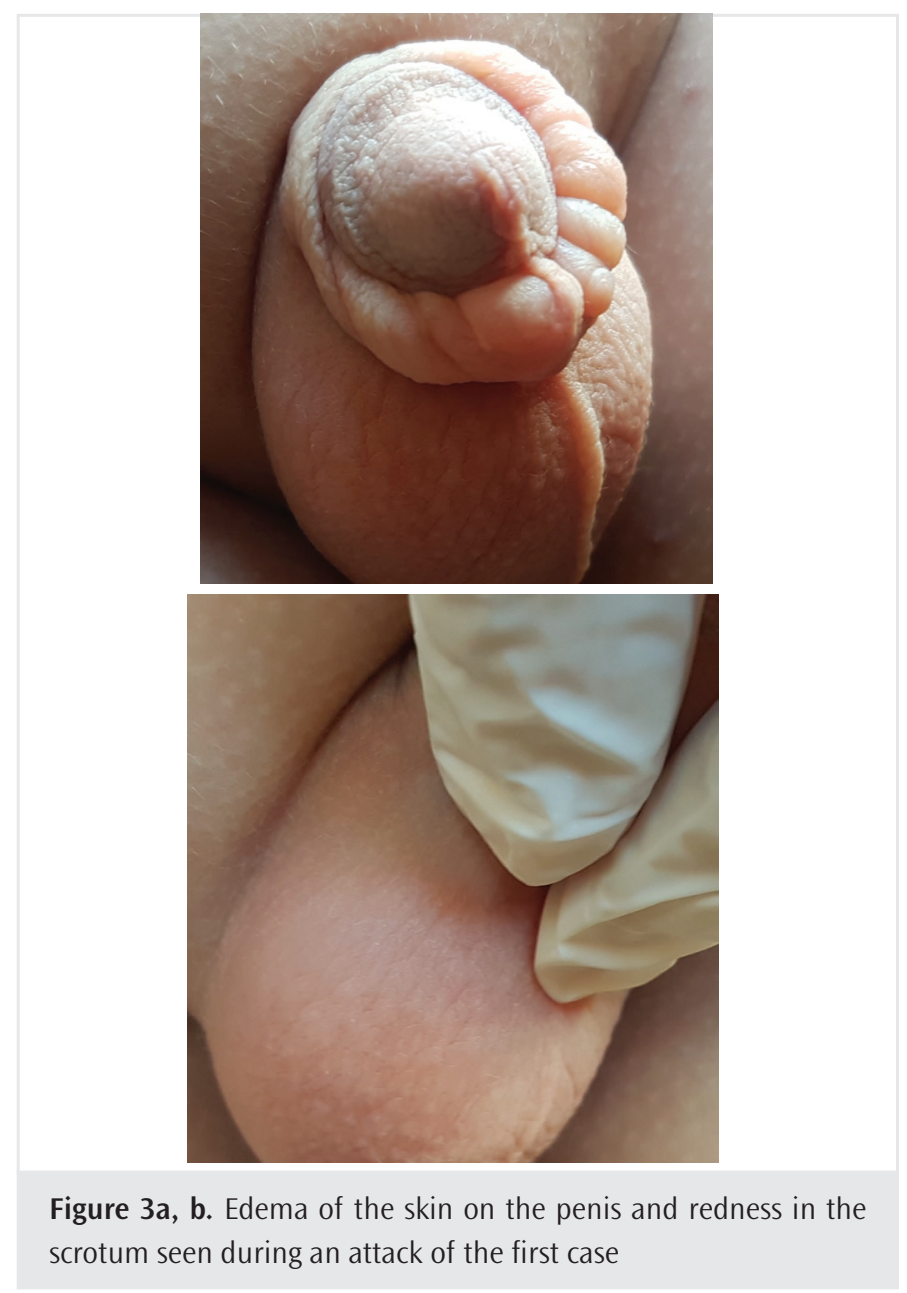

recent complaint was swelling on the face, lips and eyelids 15 days before applying to us (Figure 4). The swelling first started from the cheeks, lips and eyes, and spread to the entire face, then regressed. Previously, she had no redness, itching, history of an infection, or a history of exposure to a known allergen. There was no known history of the disease in her background. Her family history included a diagnosis of angioedema in the father, grandfather and uncle, but its type was unknown. At admission to the Pediatric Allergy and Immunology Outpatient Clinic, in the laboratory examinations requested with the preliminary diagnosis of HAO, C4 was $<0.07 \mathrm{~g} / \mathrm{L}(0.1-0.4)$ and was low. C1 INH antigen level was 38.2 (18- $40 \mathrm{mg} / \mathrm{dL}$ ) and within the reference range. The clinical and examination results of the case were compatible with $\mathrm{HAO}$, and $\mathrm{C} 1 \mathrm{INH}$ activation/function test was requested for the purpose of typing HAO. Because C1 INH function test result was reported as 43\% (70-130\%), the patient was diagnosed with $\mathrm{C} 1 \mathrm{INH}-\mathrm{HAO}$ type 2 and Icatibant treatment was started. The follow-up of the case is still ongoing (written informed consent was obtained from the child's family for the presentation).

For complement tests studied in these cases, fresh serum samples were collected in Vacutainer dry tubes and within 6 hours, $3 \mathrm{~mL}$ serum was stored at $-20{ }^{\circ} \mathrm{C}$. Frozen serum samples were studied in 72 hours to determine the level of C4, C1 INH antigenic and function levels. C4 serum level was measured in the Cobas c 501 autoanalyzer by turbidimetric method and by using the Cobas C4-2 kit (Roche, Rotkreuz, Switzerland). The C1 INH antigen level was determined on the BN II / BN ProSpec ${ }^{\circledR}$ system nephelometry instrument and using the N AS C1IN kit (Siemens, Marburg Germany). C1 INH function test was performed by working with the chromogenic Berichrom ${ }^{\circledR}$ C1-Inhibitor kit (Siemens, Marburg Germany) on the Berichrom ${ }^{\circledR}$ C1 INH coagulation automatic analyzer. To obtain plasma, 1 unit of sodium citrate solution $(0.11 \mathrm{~mol} / \mathrm{L})$ was carefully mixed with 9 units of venous blood, avoiding foam formation. After the blood sample was centrifuged at room temperature for at least 15 minutes with $1500 \times \mathrm{x}$, absorbance was measured on the photometer. The lower limits of the three tests were as follows. Serum C4 level: $\leq 0.1 \mathrm{~g} / \mathrm{L}, \mathrm{C} 1 \mathrm{INH}$ antigenic level: $\leq 0.21 \mathrm{~g} / \mathrm{L}, \mathrm{C} 1 \mathrm{INH}$ function: $\leq \% 70$. The values below these limits were considered low (4).

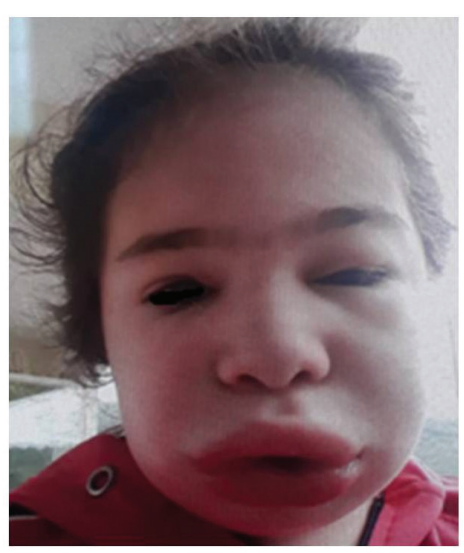

Figure 4. Angioedema in the face, eyelid and lips seen in the attack period of the second case 


\section{Discussion}

HAO was first described by William Osler in 1888 (1-3). HAO is a hereditary disease that recurs, has boundaries not clearly selected, and has a course with angioedema attacks not accompanied by pain and itching (urticaria). Although it is a rare disease, it most often develops due to a qualitative or quantitative protein deficiency in C1 INH. C1 INH is a serine protease inhibitor and is produced primarily in the liver. C1 INH deficiency or dysfunction causes the production of vasoactive and anaphylactic peptides and the increase of vascular permeability by the release of mediators such as bradykinin due to the elevated kallikrein. As a result, angioedema occurs due to plasma leaking from postcapillary venules between the dermal layers of the skin (3). Edema developing in the disease can often occur in the subcutaneous tissues, gastrointestinal tract and respiratory system. More rarely, it may appear as bladder, urethra, shoulder, hip swelling or pleural effusion. In a typical attack, angioedema is most commonly seen in the hands and feet $(2,3)$. The reason for our cases to apply to the outpatient clinic was recurrent swelling on the extremities and face. The most feared complication of HAO is laryngeal edema and has never happened in our cases. In some cases, the most common symptom may be abdominal pain due to edema in the gastrointestinal tract. Often, cases of HAO are accidentally diagnosed as acute abdomen or "FMF: familial Mediterranean fever". Considering acute abdomen, unnecessary laparoscopy and / or appendectomies are frequently performed in these cases (5). It was stated in our cases that there was sometimes abdominal pain with swelling. However, as seen in the first case, involvement of the scrotum or genital area is not a widely reported form of involvement in HAO. Rare case reports are encountered in the literature $(6,7)$.

HAO is a disease that is not known when and how often it will recur, sometimes fatal, and progresses with angioedema attacks. An attack usually reaches its peak within 24 hours. It follows a slow recovery in the next 48-72 hours and ends in 72-96 hours. In our case, the attack lasted an average of 48-72 hours. The frequency of attacks varies from person to person, from weekly episodes to monthly episodes (6,7). Our first case generally described attacks once a year until the last 4-5 months. Our second case described an attack every 2-3 months. A prodrome stage usually leads to angioedema attacks in HAO. There may be a feeling of numbness in the area where the attack will begin about an hour before the attack. In 1/3 of the cases, erythema marginatum-like rash may appear on the skin during the onset of the attack (8). Rashes are not puffy from the skin and are not accompanied by itching. It is important to differentiate erythema marginatum-like rash from urticaria before attack because urticaria plaques do not accompany attacks and itching does not occur in cases with HAO. Although our first case had erythema marginatum-like rash before swelling in the hands and feet (Figure 2a, b), our second case did not mention the rash.

If the following points are taken into consideration, HAO attack can easily be distinguished from other causes of angioedema in childhood. HAO attacks are the types of attacks that last longer (3-5 days) without any urticaria, are triggered by factors such as trauma or stress and sometimes medication in adults, and have a course with swelling in which the attack does not respond to anti-histamine, corticosteroid and adrenaline. It differs from other shorter types of angioedema, which is frequently seen in childhood due to infection or allergic-immunological mechanisms and is seen with urticaria. In adults or older children, it can also be confused with acquired or drug-induced angioedema such as ACE-inhibitor (1-3). In our cases, there was no obvious trigger for attacks.

Routine laboratory tests related to chronic urticaria-angioedema are in the reference range in HAO. On the other hand, SPT used for triggering allergens is negative. Complete blood count and biochemical values of both cases were within the reference range limits and SPT was negative. In almost all cases with HAO, serum C4 levels are low both between and during attacks. Complement $\mathrm{C} 4$ is a very good screening test in the diagnosis of HAO. Complement C2 and C3 levels are in the reference range (1-3). In both of our cases, C4 level was low, C1 INH antigen level was in the reference range and $\mathrm{C} 1 \mathrm{INH}$ function was low. Determination of $\mathrm{C} 1 \mathrm{INH}$ level and function helps both make a diagnosis and make the distinction between Type 1 and Type 2 C1 INH-HAO. In Type 1, C1 INH antigen level is decreased; however, in Type 2, C1 INH level is in the reference range, but its function is decreased. Accordingly, both of our cases were Type $2 \mathrm{C} 1 \mathrm{INH}-\mathrm{HAO}$. The $\mathrm{nC} 1 \mathrm{INH}-\mathrm{HAO}$ group, which is more common in adolescents and adults, has not been reported much in childhood in the literature $(9,10)$.

Treatments used in other angioedemas (corticosteroids, antihistamines and epinephrine) are not effective in the treatment of HAO. The treatment approach in $\mathrm{HAO}$ can be divided into four steps: i-) prevention treatment, ii-) treatment of acute attacks, iii-) short-term prophylaxis for the prevention of acute attacks, and iv-) long-term prophylaxis. Prevention measures begin with education, which includes explaining the disease to the patients and their relatives. The factors that trigger attacks should be taught to the cases. It should be kept in mind that some drugs can trigger attacks. Sick individuals' families should also be screened. A card that tells the patients what their illnesses are and which drugs and how to use in emergencies can be prepared. In acute attack treatment, the goal is to replace $\mathrm{C} 1 \mathrm{INH}$, which is deficient. In the treatment of attack, plasma-derived C1-INH (Berinert ${ }^{\circledR}$, Cinryze ${ }^{\circledR}$ ) or recombinant C1-INH (Ruconest ${ }^{\circledR}$ ) replacement, selective bradykinin B2 receptor antagonist $\left(\right.$ Firazyr $^{\circledR}$, Icatin $\left.{ }^{\circledR}\right)$, and selective plasma kallikrein inhibitor (Kalbitor ${ }^{\circledR}$ ) can be used. In our country, recombinant C1INH and kallikrein inhibitor are still not available. On the other hand, İcatin has been covered by SGK since the beginning of 2019. For this purpose, primarily plasma-induced or recombinant $\mathrm{C} 1 \mathrm{INH}$ replacement is preferred; but when it is not available, bradykinin B2 receptor antagonist, kallikrein inhibitör or as a last resort, fresh frozen plasma (FFP) can be given (2). In our country, Cinryze ${ }^{\circledR} /$ ícatin $^{\circledR}$ can be used in attacks and is present in emergency units. In general, longterm prophylaxis is recommended for patients who experience more than one attack per month, are affected by these attacks for more than 5 days a month, or have a history of respiratory obstruction, but the criteria are not clear (2). Three groups of drugs are used in long-term prophylaxis. These are products that contain weak androgens (danazol, stanozolol), anti-fibrinolytics (aminocaproic acid, tranexamic acid) and C1 INH. Another treatment approach in cases with HAO is short-term prophylaxis to prevent acute attacks during interventions such as tooth extraction or surgical operation known to trigger attacks or immediately 
after trauma. FFP, weak androgens and C1 INH replacement can also be used for short-term prophylaxis (10). In our country, drugs such as weak androgens and anti-fibrinolytics can be used for short or long term prophylaxis, but C1-INH products from plasma are not covered by SGK.

Despite the fact that C1-INH antigen level of the laboratory tests used in the diagnosis is easier and can be studied in most university hospitals around the world and Turkey, C1-INH function is widely studied with chromogenic method in private laboratories in the world, as in our cases.

Although ELISA test is also used to measure activity (function), it has not been found as sensitive as the chromogenic method (11-13). Although ELISA and chromogenic method have been reported to have similar positive predictive value in previous publications, the chromogenic method has been found to have a higher negative predictive value (12). In our study, C1 INH function could only be studied with the chromogenic method. With the chromogenic method, the sensitivity of the $\mathrm{C} 1 \mathrm{INH}$ function test is given as $57 \%$ and the specificity as $100 \%$. The sensitivity of $\mathrm{C} 1$ INH antigen test has been reported as $97 \%$ and its specificity as $100 \%$ (11). Serum C4 level was found to be $85.7 \%$ sensitive and $85 \%$ specific in detecting $\mathrm{C1}$ INH deficiency in asymptomatic HAO cases $(11,13)$.

If possible, both (chromogenic and ELISA) test results should be evaluated together with clinical history, family history, and C4 levels. It is recommended to repeat the suspicious ELISA test results with the chromogenic method. Especially, the chromogenic method stands out as a method that needs more attention in terms of correct storage and working of the sample. Genetic testing is the confirmatory and diagnostic test that will be applied when necessary (13). Our cases did not use any medication at the time of the tests and they did not have any disease other than HAO.

The strength of our case report is that a very rare clinical picture could be confirmed by laboratory findings made from serum, and the weak side is that the genetic Type 2 HAO-specific mutation could not be studied due to financial impossibility.

\section{Conclusion}

In cases where recurrent angioedema is not accompanied by urticaria, HAO should be considered and serum complement C4 level should be evaluated as screening test in the first stage. In cases with low complement C4 levels, C1 INH antigen level should be examined, and even if it is within reference range, $\mathrm{C} 1 \mathrm{INH}$ activity test should be kept in mind since $\mathrm{C} 1 \mathrm{INH}$ - HAO Type 2 can occur. Where all of these levels are within the reference range, further investigations (investigating whether factor 12, plasminogen and angiopoietin mutations are available) for the nC1 INH-HAO group, formerly called Type 3, should be requested (14-15).

Informed Consent: Written informed consent was obtained from the child's family for the presentation.
Peer-review: Externally peer-reviewed.

Author Contributions: Concept - Ö.Ö.; Design - Ö.Ö.; Data Collection and/or Processing - Ö.Ö.; Analysis and/ or Interpretation - Ö.Ö., H.Ç.; Literature Search - Ö.Ö., H.Ç.; Writing - Ö.Ö., H.Ç.

Conflict of Interest: No conflict of interest was declared by the authors.

Financial Disclosure: The authors declared that this study received no financial support.

\section{References}

1. Ozdemir $\mathrm{O}$. New developments in type of hereditary angioedema with normal Cl-inhibitor level. MOJ Immunol 2019; 7: 1-2.

2. Bowen T, Cicardi M, Bork K, Bork K, Zuraw B, Frank M, et al. Hereditary angiodema: a current state-of-the-art review, VII: Canadian Hungarian 2007 international consensus algorithm for the diagnosis, therapy, and management of hereditary angioedema. Ann Allergy Asthma Immunol 2008; 100(1 Suppl 2): \$30-40.

3. Zuraw BL, Christiansen SC. HAE pathophysiology and underlying mechanisms Clin Rev Allergy Immunol 2016; 51: 216-29.

4. Özdemir Ö, Elmas B. Prevalence and Clinical Manifestations of Hereditary Angioedema in Untested Close and Distant Blood Relatives of Hereditary Angioedema Index Patients in a City, Turkey. JAREM 2017; 7: 51-7.

5. Bahceci SE, Genel F, Gulez N, Nacaroglu HT. Coexistence of hereditary angioedema in a case of familial mediterranean fever with partial response to colchicine. Cent Eur J Immunol 2015; 40: 115-6.

6. Abuzakouk M, AlMahmeed N, Memisoglu E, McManus M, Alrakawi A. Hereditary angioedema Type II: First presentation in adulthood with recurrent severe abdominal pain. Case Reports Immunol 2018; 2018: 7435870.

7. Iwanami K, Okano T, Ohara O, Morio T. Recurrent acute abdomen as the main manifestation of hereditary angioedema. Intern Med 2019; 58: 213-6.

8. Martinez-Saguer I, Farkas H. Erythema marginatum as an early symptom of hereditary angioedema: Case report of 2 newborns. Pediatrics 2016; 137 : e20152411.

9. Longhurst HJ, Bork K. Hereditary angioedema: an update on causes, manifestations and treatment. Br J Hosp Med (Lond) 2019; 80: 391-8.

10. Jose J, Zacharias J, Craig T. Review of select practice parameters, evidencebased treatment algorithms, and international guidelines for hereditary angioedema. Clin Rev Allergy Immunol 2016; 51: 193-206.

11. Tarzi MD, Hickey A, Forster T, Mohammadi M, Longhurst HJ. An evaluation of tests used for the diagnosis and monitoring of $\mathrm{C} 1$ inhibitor deficiency: normal serum C4 does not exclude hereditary angio-oedema. Clin Exp Immunol 2007; 149: 513-6.

12. Wagenaar-Bos IG, Drouet C, Aygoren-Pursun E, Bork K, Bucher C, Bygum A, et al. Functional C1-inhibitor diagnostics in hereditary angioedema: assay evaluation and recommendations. J Immunol Methods 2008; 338: 14-20.

13. Li HH, Busse P, Lumry WR, Frazer-Abel A, Levy H, Steele T, et al. Comparison of chromogenic and ELISA functional C1 inhibitor tests in diagnosing hereditary angioedema. J Allergy Clin Immunol Pract 2015; 3: 200-5.

14. Ozdemir 0. Tekrarlayan anjiyoödem atakları ile başvuran hastaya akılcı yaklaşım. Klinik Tıp Pediatri Dergisi 2019; 11: 64-73.

15. Öner Özdemir. Innovations in Hereditary Angioedema Pathophysiology. SCIE 2019; 30: 355-61. 